\title{
SUNFLOWER BREEDING FOR RESISTANCE TO FUSARIUM
}

\author{
Gontcharov, S.V. ${ }^{*}$ Antonova, T.S. and Saukova, S.L. \\ All-Russia Research Institute of Oil Crops "V.S. Pustovoit" (VNIIMK), Filatova 17, \\ 350038, Krasnodar, Russia
}

Received: October 15, 2006 Accepted: December 05, 2006

\section{SUMMARY}

Fusarium fungi have grown from a minor pathogen of sunflower crop to a major problem of sunflowers in Russia. The aim of this work was breeding for resistance to this new major pathogen, combining field and laboratory testing in the framework of VNIIMK hybrid sunflower breeding program. Four segregated hybrid combinations selected on the basis of their field resistance to different pathogens were used as breeding material. Three of them were doublecross combinations: $\mathrm{F}_{3}$ R-14 $\times\left(\right.$ VK-591 $\times$ VK-539), $\mathrm{F}_{4}$ VK-623 $\times($ HA-385 $\times$ VK-653) and $F_{4}\left(V K-678 \mathrm{~A} \times\right.$ VK-464) $\times$ VK-541, the fourth one was a cross $\mathrm{F}_{3}$ VK-680 $\times$ O.P. variety Leader. It was shown that combination of laboratory testing and individual selection can rapidly improve the Fusarium resistance of a segregated population - the share of families without plants with Fusarium damage symptoms was $62.5 \%$ among the selected plants offspring while only $18.2 \%$ of such families were found in the breeding nursery the next year after selection. As a result, a number of new breeding lines were developed that exhibited no Fusarium symptoms in the field.

Key words: breeding, Fusarium, resistance, sunflower

\section{INTRODUCTION}

Sunflower is the main oil crop in Russia. In the last decade, the average sunflower acreage was about 3.5-4.5 million ha. Breeding for resistance (or at least tolerance) to pathogens has always been considered an important aim in sunflower breeding. Fusarium is a major pathogen in many crops. For sunflowers, it had been considered a minor pathogen (Tikhonov, 1992; Gulya, Rashid, Maširević, 1997). In recent years, however, Fusarium has become a serious problem for sunflower crop in Russia. First report was made in the 1990s, when five Fusarium species were found in the sunflower fields of Voronezh and Belgorod regions of Russia (Yakutkin, 1995). In Krasnodar region, 12 different species and varieties of Fusarium ( $F$.

* Corresponding author: Phone: (8612) 75-85-43; e-mail: serggontchar@mail.ru 
oxysporum, F. oxysporum var. orthoceras, F. sporotrihiella var. poae, F. sporotrihiella var. tricinctum, $F$. sporotrihiella var. sporotrichioides, $F$. semitectum, $F$. gibbosum, $F$. moniliforme, $F$. solani, $F$. solani var. argillaceum, $F$. javanicum and $F$. heterosporum) were found during the phytopathological surveys in 1999-2001 (Antonova, Araslanova, Saukova, 2002). Their pathogenicity for sunflowers was also demonstrated. Among them, F. oxysporum var. orthoceras was the most widely spread, and $F$. sporotrihiella var. sporotrichioides was the most aggressive one. During the last decade Fusarium was regularly registered in the breeding nurseries of All-Russia Research Institute of Oil Crops in Krasnodar. In 2006, for example, we found $19-28 \%$ damaged plants on average in the sunflower hybrid trial. Some hybrid plots had up to $80 \%$ of damaged plants. A special breeding program for Fusarium resistance was started in 2001 using a laboratory test developed at VNIIMK. Field experiments demonstrated a high level of resistance to the pathogen in the newly developed lines.

\section{MATERIAL AND METHODS}

\section{Plant and fungal materials}

Two different samples of Fusarium were used in the test: F. oxysporum var. orthoceras as the most widely spread Fusarium pathogen on sunflower plants in Krasnodar region, and $F$. sporotrihiella var. sporotrichioides as the most aggressive one.

Plant material included four segregated hybrid combinations (and their offspring). The combinations were made between promising and released inbred lines, selected on the basis of field evaluations for resistance to different pathogens. Three of them were double crosses: $\mathrm{F}_{3}$ R-14 $\times\left(\mathrm{VK}-591 \times\right.$ VK-539), $\mathrm{F}_{4}$ VK-623 $\times$ $(\mathrm{HA}-385 \times \mathrm{VK}-653)$ and $\mathrm{F}_{4}(\mathrm{VK}-678 \mathrm{~A} \times \mathrm{VK}-464) \times \mathrm{VK}-541$, the last one was a cross F3 VK-680 $\times$ O.P. variety Leader.

\section{Methods}

A method developed in the Immunology Laboratory of VNIIMK was used in the test (Saukova, 2001). Two-day-old sunflower plantlets were placed for 6 hours on perforated covers of Petri dishes containing a 15-day-old Fusarium culture. Two days later they were incubated in a moisture chamber. After that, plantlets were visually evaluated, best plants were placed in the soil and cultivated in the greenhouse till maturity. Seeds were collected after self-pollination and used for field resistance test and breeding purposes. In subsequent years only healthy sunflower plants were selected and self-pollinated. The mass selection method was used in the final stage of breeding. 


\section{RESULTS}

Breeding nurseries of VNIIMK are regularly inspected by phytopathologists. In the last decade, different species of Fusarium fungi became common pathogens of sunflower plants. For example, the average number of plants with different symptoms of Fusarium damage was $21 \%$ in the nursery of breeding material in 2001, varying from 0 to $100 \%$ in different lines.

Four segregating populations of sunflower hybrids were selected for our work in the breeding nursery. They showed maximum field resistance to the registered pathogens among the tested breeding material. Their seeds were used for selection based on a laboratory method. After treatment with $F$. oxysporum var. orthoceras, the seedlings showed different levels of damage - from a hardly visible necrosis to full destruction. Individual plantlets with minimum visible symptoms of Fusarium damage and maximum root growth rate were selected and transplanted in the greenhouse.

Treatment by $F$. sporotrihiella var. sporotrichioides produced more severe results - all seedlings had greatly reduced root length (less than $5 \mathrm{~mm}$ ). The plantlets with maximum shoot growth rate and green cotyledons (most of them were of brownish color) were selected for transplanting.

Equal numbers of plants were selected from the four populations after treatment by both pathogens. The sunflower plantlets treated by $F$. sporotrihiella var. sporotrichioides had to form lateral roots because their main roots were heavily damaged. The transplanted plants were self-pollinated and their seeds were after harvest used to assess their field resistance.

The field experiment was started in 2001. The spring was unusually cold, with high soil humidity, and it was followed by a hot and dry summer. Such weather conditions greatly affected the health status in the test - Phomopsis helianthi (the most frequent pathogen in previous years) was registered seldom and on the most susceptible specimens only, while Fusarium and Verticillium fungi were the most frequent pathogens of sunflower plants in that year. The average number of plants with different symptoms of Fusarium damage was $21 \%$ in the nursery of breeding material. However, among the offspring of plants selected by laboratory test, only $11 \%$ of plants were damaged. The number of families without any visible Fusarium symptoms was $62.5 \%$ while only $18.2 \%$ of such families were found in the breeding nursery (Table 1 ).

Table 1: Frequency of sunflower families with different levels of field resistance to Fusarium after individual selection

\begin{tabular}{lcccc}
\hline \multirow{2}{*}{ Nursery } & \multicolumn{4}{c}{ Damaged plants, \% } \\
\cline { 2 - 5 } & $0 \%$ & $1-39 \%$ & $40-60 \%$ & $61-100 \%$ \\
\hline Breeding material (check) & 18.2 & 67.0 & 14.8 & 0.0 \\
Offspring of selected plants & 62.5 & 29.2 & 8.3 & 0.0 \\
\hline
\end{tabular}


The first set of experiments clearly indicated that a combination of the laboratory test developed in the VNIIMK's Immunology Laboratory and individual selection could rapidly improve Fusarium resistance in a segregated population.

The next stage was individual selection based on field evaluation of resistance. Seed samples were taken only from plants free of disease symptoms. When lines were stabilized, we used mass selection based on field evaluation of resistance mainly - only lines with minimum amount of damaged plants (0-5\%) were included in the next year's nursery.

Table 2: New lines susceptibility (\%) to Fusarium fungi under field conditions

\begin{tabular}{lcc}
\hline Line & 2005 & 2006 \\
\hline FR-45-1 (susceptible check) & 100 & 62 \\
FR-23-1 & 0 & 0 \\
FR-22-2 & 2 & 3 \\
FR-4-1 & 0 & 5 \\
FR-11-2 & 0 & 5 \\
\hline Average & 10 & (34 lines total) \\
\hline
\end{tabular}

In this way we developed a large number of lines with high level of field resistance to Fusarium fungi (Table 2). These lines are presently being crossed with tester lines to study their combining ability.

\section{CONCLUSIONS}

The applied laboratory method of Fusarium resistance testing developed in VNIIMK's Immunology Laboratory (seedlings infection) demonstrated its effectiveness. Combination of the method and individual selection can rapidly improve Fusarium resistance in a segregated sunflower population. New elite breeding lines were developed and included in the hybridization program of VNIIMK.

\section{REFERENCES}

Antonova, T.S., Araslanova, N.M. and Saukova, S.L., 2002. Harmfulness of sunflower disease caused by Fusarium sp. in Krasnodar region. Reports of Russian Academy of Agricultural Science 3: 6-8.

Gulya, T., Rashid, K.Y. and Maširević, S., 1997. Sunflower diseases. pp. 263-380, In: Sunflower Technology and Production, Ed.: A.A. Schneiter, ASA, CSSA and SSSA. Agron. Monogr. 35. USA.

Saukova, S.L., 2001. Laboratory test for evaluation of Fusarium resistance in sunflower seedlings. In: Proc. Int. Conference of Young Researchers. Kharkov, Ukraine. (In Russian). pp. 113-114.

Tikhonov, O.I., 1992. Sunflower diseases. In: Sunflower Biology, Plant Breeding and Growing Technology. Moscow: Agropromizdat, Russia (In Russian). pp. 263-380.

Yakutkin, V.I., 1995. Fusarium diseases of sunflower and phytosanitary monitoring problem in Russia. In: Plant Protection under Agroindustrial Complex Reformation: Economy, Effectiveness, Ecology. Sanct-Petersburg, Russia. (In Russian). pp. 108. 


\title{
SELECCIÓN DE GIRASOL POR RESISTENCIA A FUSARIUM
}

\author{
RESUMEN
}

Los hongos del género Fusarium se han transformado desde menor patógeno, en el problema principal de la producción de girasol en Rusia. El objetivo de esta investigación fue selección para incrementar la resistencia a este nuevo patógeno dominante. Fueron combinadas las investigaciones de campo y de laboratorio, dentro del programa de selección de híbridos de girasol en VNIIMK. Cuatro combinaciones híbridas separadas, elegidas sobre la base de la resistencia de campo a diferentes patógenos, fueron utilizadas como material de selección. Tres combinaciones fueron cruzamientos triples: $\mathrm{F}_{3} \mathrm{R}$ $14 \times\left(\mathrm{VK}-591 \times\right.$ VK-539), $\mathrm{F}_{4}$ VK-623 $\times\left(\mathrm{HA}-385 \times\right.$ VK-653) y $\mathrm{F}_{4}(\mathrm{VK}-678 \mathrm{~A} \times$ VK-464) $\times$ VK-541, mientras que la cuarta fue el simple cruzamiento $F_{3}$ VK$680 \times$ la variedad de fecundación cruzada, Leader. Se ha mostrado que la combinación de la investigación de laboratorio y la selección individual puede en corto tiempo mejorar la resistencia a Fusarium en la nueva población formada - mientras que la porción de familias sin plantas dañadas por Fusarium, fue $18.2 \%$ en melisa, un año despus de la selección, este número subió a $62.5 \%$ en las descendencias elegidas. Como resultado [de la selección exitosa], fue formado el gran número de líneas de selección cruzamientos triples que no mostraban síntomas de Fusarium en las condiciones de campo.

\section{SÉLECTION DE TOURNESOL POUR LA RÉSISTANCE AU FONGUS FUSARIUM}

\section{RÉSUMÉ}

En Russie, le fongus Fusarium s'est développé de pathogène mineur en problème majeur du tournesol. Le but de ce travail était une sélection pour la résistance à ce nouveau pathogène dominant. Des recherches ont été faites autant sur le terrain qu'en laboratoire dans le cadre du programme VNIIMK de sélection d'hybrides du tournesol. Quatre combinaisons isolées d'hybrides choisis d'après leur résistance envers différents pathogènes sur le terrain ont été utilisées comme matériel de sélection. Trois d'entre elles étaient des combinaisons de croisements triples: $\mathrm{F}_{3}$ R-14 $\times\left(\mathrm{VK}-591 \times\right.$ VK-539), $\mathrm{F}_{4}$ VK-623 $\times$ (HA-385 $\times$ VK-653) et $\mathrm{F}_{4}(\mathrm{VK}-678 \mathrm{~A} \times \mathrm{VK}-464) \times \mathrm{VK}-541$, et la quatrième était un croisement $\mathrm{F}_{3}$ VK-680 $\mathrm{x}$ variété allogame Leader. Il a été démontré que la combinaison de test de laboratoire et de sélection individuelle pouvait rapidement améliorer la résistance au Fusarium dans les populations nouvellement créées - tandis que la part des familles des plantes non touchées par le Fusarium était de $18,2 \%$ dans la pépinière un an après la sélection, celle de la progéniture des plantes sélectionnées était de 62,5\%. Le résultat (sélections réussies) est un grand nombre de lignées de sélection qui n'ont pas montré de symptômes de Fusarium sur le terrain.

Presented at:

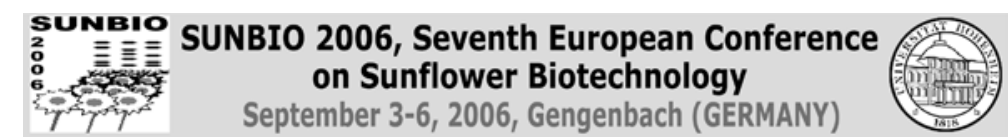


